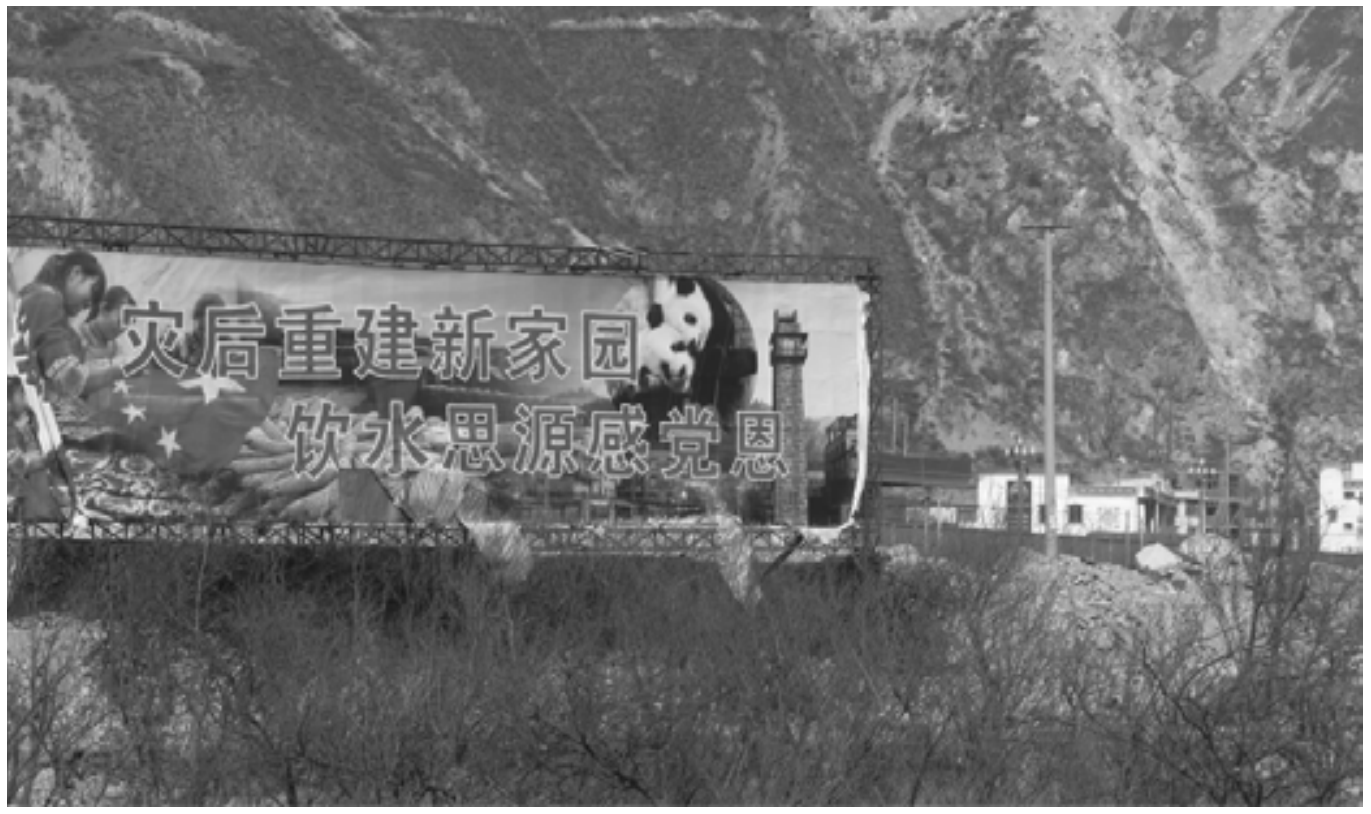

\title{
Be Grateful to the Party! \\ How to Behave in the Aftermath of a Disaster
}

Christian Sorace

During the earthquake that hit Sichuan province in 2008, over 7,000 classrooms in shoddily constructed schools collapsed, killing at least 5,000 children. Grieving parents staged protests and called for an official investigation to punish the officials and building contractors found responsible for the tragedy. The Communist Party responded with more than just censorship, imprinting its own narrative on the rescue and reconstruction, so the slogans written by grieving parents are now doubly buried underneath monuments to the Party's glory and benevolence.
'Reconstructing the homeland in the aftermath of disaster. When you drink the water, remember its source: be grateful to the Party!' Photo by the author.

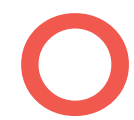
n 12 May 2018 at 2:28 pm in the afternoon, when children were attending school, a 7.9 magnitude earthquake struck the Wenchuan region of Sichuan Province. Over seven thousand classrooms in shoddily constructed schools collapsed. The killer buildings were dubbed 'tofu-dregs schoolhouses' (doufuzha xiaoshe)toufu-dregs are soft and mushy remnants from the process of making tofu, a metaphor for slipshod construction coined by former premier Zhu Rongji during an inspection visit in 1998 to the site of a newly built dam that had collapsed. In Sichuan's schools, at least five thousand children died. Grieving parents staged protests and called for an official 
investigation into why the schools collapsed and punishment of the officials and building contractors found responsible for the tragedy.

Travelling through the wreckage at the end of May 2008, a couple of weeks after the quake, poet and self-styled barefoot ethnographer Liao Yiwu $(2009,100)$ documented the rage of grieving parents condensed in the following slogans:

Demand justice for the dead students and teachers of Juyuan Middle School

Demand that the government severely punish the murderers responsible for the collapsed school buildings of Juyuan Middle School!

Recover the debt of blood for the people responsible for causing the toufu-dreg construction' of school buildings!

The Communist Party responded with more than censorship. It imprinted its own narrative on the rescue and reconstruction. During my 18 months of fieldwork between January 2012 and August 2013, I photographed and wrote in my notebook numerous slogans praising the Communist Party's disaster relief effort:

\section{An earthquake doesn't care, the Party} does.

In times of disaster, the Party is there In this life, walk with the Party.

Be grateful to the mighty Communist Party for our new roads, new bridges, and new houses.

Reconstructing the homeland in the aftermath of disaster. When you drink the water, remember its source: be grateful to the Party!

In the contrast between these two sets of observations lies the source of the Communist Party's authority: the ability to control the discursive parameters through which people talk about, engage, and make sense of their world. Or, as $\mathrm{Xi}$ Jinping insists, patriotic citizens must defend their 'discursive rights' (huayuquan) to 'tell China's stories well' (jianghao zhongguo gushi).

Those who tell a different story have no such rights. The slogans written by grieving parents are now part of the landscape of ruins, hieroglyphs of lost futures. They are doubly buried underneath monuments to the Party's glory and benevolence. In China, words like 'manmade disaster' (renhuo), 'responsibility' (zeren), and 'blood debt' (xuezhai) are added to the rubble of words that cannot be excavated. An inverted Tower of Babel that reaches down to the abyss.

\section{Affective Sovereignty}

The Communist Party's 'discursive rights' are central to its authority and power because words are not disembodied modes of communication but attach us to the world. The Communist Party unabashedly organises political life on the basis of this understanding. In the body politic, words and affects are not the private domain of the individual but the social ties that hold together public life. As a result, how people in China talk and feel falls under the jurisdiction of Party sovereignty-what I call affective sovereignty (Sorace forthcoming).

In the aftermath of the 2008 Sichuan earthquake, the Party encouraged disaster victims to 'bid farewell to sorrow and face the future' (gaobie chuangtong, mianxiang weilai), and to move out from under the dark clouds of 'tragedy' and into the radiance of 'heroism' (cong beizhuang xiang haomai). Less than a handful of months after the earthquake, all Chinese citizens were asked to 'transform the public enthusiasm' (minzhong reqing) for disaster relief into preparation for the Olympics, and to 'overcome disaster and welcome glory' (chuanyue zainan, yingjie 
guangrong)-the implication being that the expression of individual grief, as negative affect, would be an affront to national pride.

The Communist Party provides the acceptable guidelines for the expression and temporality of grief. One must not mourn for too long or let grief get in the way of optimism. Sadness must not metastasise into rage. Face the future rather than the past. The past is a dangerous place to live. Above all, do not dwell on the questions posed by the dead (Bandurski 2015). All of this affective corralling and cajoling is de-personalising and merciless. The imperative to surrender to the demands of the world is eloquently captured by Roland Barthes' (2010, 126) reflections on mourning his mother's death. 'I resist the world, I suffer from what it demands of me, from its demands' (emphasis added) to rejoin the charade that life continues as if nothing changed. There is an unrelenting reality principle thrown up in response to death, and in China it is the Communist Party who defines the reality to which one must surrender in order to survive.

In the earthquake zone, those who were left cold by the warm embrace of the Party were labelled 'unruly subjects' (diaomin). As one internal Party document put it: for 'individual parents who are emotionally out of control (xinli shiheng) and engage in physical conflict' a 'public security conversation' would be needed.

\section{The Miracle of Post- disaster Reconstruction}

The Communist Party's official narrative of the post-2008 Sichuan earthquake reconstruction is that it was a 'miracle' (qiji). The reconstruction is celebrated as an example of how 'hard work for two to three years can leap across (kuayue) twenty years of monumental change'. Over five million people rendered homeless by the earthquake-more than the entire population of Los Angeleswere moved into new homes within a three- year period. Celebrating this 'miracle', on the third anniversary of the earthquake, the People's Daily praised the Communist Party for being capable of this kind of 'faith', 'mobilisation capability', and 'ideological dedication to the people.'

Far from disseminating empty propaganda, the Communist Party was re-enacting a variation of its foundational narrative of legitimacy: without Party benevolence, disaster victims would be helpless, scattered, and exposed to the devastating power of nature. For the individual, nature is terrifying and deadly, but under the Party's collective leadership, wisdom, and protection, nature can be defeated. Another way of saying, without us, there is only 'chaos' (luan). In this familiar mantra resonates the Party dictum 'without the Communist Party, no new China' (meiyou gongchandang, meiyou xin zhongguo), conveying the message don't ask too many questions and be grateful. Two years after the earthquake, the Communist Party organised 'gratitude education' (gan'en jiaoyu) activities among the earthquake survivors. The gift of the reconstruction required affective reciprocation.

For the Communist Party to be the agent of salvation, the devastation caused by the Sichuan earthquake could not be perceived or discussed as a 'manmade catastrophe' (renhuo) in which school buildings collapsed due to shoddy construction materials, corruption, and regulatory negligence. The Sichuan earthquake was a 'natural disaster' (tianzai), for which no one could be held responsible. The Communist Party's authority in the earthquake zone rested on the fragile distinction between 'natural disaster' and 'manmade catastrophe'. The discourse of 'natural disaster' had to be reinforced like a structurally damaged building on the verge of collapse. Official media outlets were banned from reporting on the 'toufu-dreg' schools, dead children, and protesting parents. Party authorities were tireless in asserting that the Sichuan earthquake was 'beyond any doubt a natural disaster' and 'an act of nature that could not be prevented'. 
Activists, like Tan Zuoren, who persisted in asking uncomfortable questions were arrested on charges of incitement to subvert state power' (shandong dianfu guojia zhengquan). Most China watchers view this crime to be a meaningless, catch-all category for the state security apparatus to arrest whomever they deem threatening. I suggest, however, that it means what it says. As Mao once quoted Confucius, 'a single word may rejuvenate a country (yi yan xing bang), a single word may bring disaster to a country' (yi yan sang bang). Or as Confucius $(2014,37)$ also said, 'in the matter of language, a gentleman leaves nothing to chance.'

\section{Orphans}

The government never publically released the names of the schoolchildren who died during the earthquake, despite its promise to do so. To keep that promise would mean answering, or at least acknowledging, artist and activist $\mathrm{Ai}$ Weiwei's questions: 'Who are they? What pain did they endure while alive, what grief do they provoke, now dead?' (Sorace 2014). It would mean allowing the names of the dead to live on in the questions of the living. Ai Weiwei's memory wall only provides a temporary shelter for names orphaned from their owners.

Despite Ai Weiwei's international fame, the Chinese Communist Party has discursively defeated him at home. When it is not censored, Ai's confrontational message and style of activism does not resonate with the majority of Chinese citizens. His activism and artwork on the earthquake shook without damaging the Party's discursive hegemony. Instead of following Ai's call to reject 'the erasure of your memory' and reflect on the lives and deaths of the earthquake victims, most Chinese citizens commemorate the Communist Party's response to the Sichuan earthquake and celebrate its hosting of the 2008 Beijing Olympics. Twin dates marking China's glory and reappearance on the world historical stage. These triumphs cannot be interrogated without calling into question the symbolic foundations of the Communist Party's legitimacy.

\section{Discursive Dictatorship}

In his book on censorship, Nobel Prize winning author J.M. Coetzee $(1997,15)$ reflects on how the language of the state permeates the soul, and slips into the lines of even the most precise and vigilant of writers. Coetzee's point is that we cannot escape from the language under which we are pinned: 'For there is nothing outside the theater, no alternative life one can join instead. The show is, so to speak, the only show in town. All one can do is to go on playing one's part, though perhaps with a new awareness, a comic awareness.' As long as the Chinese Communist Party is writing the script, it will remain in power.

Discursive control is a more likely explanation of Xi Jinping's governance strategy than some despotic urge to become emperor. It is also entirely foreign to the English-speaking China commentariat who believes that words are the mere shadow games of power, and that Communist Party discourse is empty propaganda. Perhaps the parents of dead children whose names cannot be publically commemorated would disagree.

But the Communist Party's power depends on more than the redaction of memory-it is revitalised through the capture of emotions. After all, there are endless ways to touch the heart: the relief of still being alive; the dread of uncertainty; the submission to optimism; the exhaustion of speaking to a brick wall-all reasons to be grateful to the Communist Party. 